\title{
The Advantages of Targeting the Real Exchange Rate
}

\author{
Christos. C. Paraskevopoulos \\ York University and the Athenian Policy F orum \\ John Paschakis \\ American University of Beirut and the Athenian Policy Forum
}

\begin{abstract}
This paper uses a simple open-economy macroeconomic framework to explore the implications of real exchange rate targeting for the behavior of real output, the domestic real interest rate, trade account, net forei gn asset holdings, and the inflation rate. It finds that a more depreciated level of the real exchange rate decreases the domestic real interest rate and net foreign debt, and leads to a higher level of output and net exports. For inflation control, given price stick iness real exchange rate targeting may not lead to higher rates of inflation. The results are consi stent with the after-effects of EM S currency realignment. They also imply that a "real targets approach" to exchange rate policy rather than a "nominal anchor approach" may be more appropriate for the European Union inflation-prone countries and the high inflation developing countries.
\end{abstract}

*Correspondence Address: Department of Economic, Atkinson College, York University, 4700 Keels Street, Toronto, Ontario, Canada M 3J 1P3, (Tel.) 416-736-5218, (Fax)416736-5188, (E-mail)chrisp@yorku.Ca.

*We would like to thank two anonymous referees for their helpful comments. The second author is grateful to the American University of B eirut for financial support(Long Term Development Grant).

(C) 2000 - Center for International E conomics, Sejong Institution. All rights reserved. 
- JEL Classification: E52, F31, F32

- Key Words: Real Exchange Rate Targeting, Foreign Exchange Market, Current account

\section{Introduction}

Inflation-prone countries, both in the European M onetary System (E M S) and outside, have often used a nominal exchange rate anchor as a means of achieving 'inflation convergence'. Pegging their currencies to a relatively low-inflation currency such as the deutsch-mark or the U.S. dollar, and relying on high interest rate policies to defend the exchange rates, they have attempted to contain and roll back inflationary pressures. While this policy helped them reduce inflation substantially relative to low inflation countries, it also generated persistent real exchange appreciations, losses in international competitiveness, large trade deficits, and serious currency devaluation crises. In the 1990s, some good examples are provided by Finland and M exico, and also by Britain, Italy and Spain within the Exchange Rate Mechanism (ERM) of the EMS. In all of these cases, a rigid nominal exchange rate regime combined with strict anti-inflation policies led to cumulative real exchange rate over-valuations and the eventual collapse of the Finnish markka and the EM S currencies in 1992, and of the Mexican peso in $1994 .{ }^{1}$ It has frequently been suggested (D ornbusch [1989], Dornbusch, Goldfajn and Valdés [1995]) that countries with higher than average inflation rates can escape the problems posed by pegged nominal exchange rates if they pursue a fixed real exchange rate policy. For instance, had these countries adjusted the nominal exchange rate according to the difference between foreign and domestic inflation so as to maintain a constant but competitive real exchange rate, they would have avoided real exchange rate over-valuations and high interest rates, and they would have only experienced moderate inflation. ${ }^{2}$

Given this background, this paper uses a simple open-economy macroeco-

1. Analysts agree that the appreciation of the real exchange rate and the current account were the main causes behind the EM S currency re-alignment and the devaluation of the markka and peso. See, for example, Dornbusch et al. [1995], Székely [1996], Bruno [1995] and Edwards [1996], among others. 
nomic framework to explore the implications of real exchange rate targeting for the behavior of real output, the domestic real interest rate, trade account, net foreign assets, and the inflation rate. It finds that a more depreciated level of the real exchange rate decreases the domestic real interest rate and real net external debt, and leads to a higher level of output and net exports. For inflation control, given price sluggishness, real exchange rate targeting may not lead to higher rates of inflation. The findings of this paper are consistent with the after-effects of EMS currency re-alignment, which had consisted of lower real interest rates and a significant improvement of international competitiveness, net exports, and real economic activity in the devaluing member countries of the system. They also imply that a "real targets approach" to exchange rate policy rather than a "nominal anchor approach" may be more appropriate for the European Union inflation-prone countries and the high inflation developing countries with nominal exchange rate targets. The results are of interest in view of the $1994 \mathrm{M}$ exican peso crisis, the uncertainty that surrounded the European exchange rate arrangements, especially after the 1992 EM S currency collapses, and the 1997 Asian currency crisis. However, the effects of real exchange rate targeting may differ qualitatively depending on whether the economy is initially a net creditor or debtor.

It is by now well accepted that the real exchange rate is a variable that is implicitly or explicitly targeted by policy makers ( $M$ ontiel and Ostry [1991]). The real exchange rate is a key relative price in an open economy, and Calvo, Reinhart and Végh [1995] view it as "probably the most popular real target." "In practice, the ultimate targets of stabilization policies include the real exchange rate .... "(K lein [1990, p. 758]). Several countries with high rates of inflation historically have adopted a policy that fixes the real exchange rate to avoid losses of competitiveness, including Argentina, Brazil, and Chile (Williamson [1981]). Also, in the literature, papers dealing with the issue of real exchange rate targeting include Rodriguez [1981], Dornbusch [1982], Adams and Gros [1986], Lizondo [1991, 1993], M ontiel

2. This suggestion is directed towards the European Union inflation-prone countries (i.e., Italy, Greece, Portugal and Spain) and also the high-inflation developing countries with nominal exchange rate targets. 
and Ostry [1991, 1992], Calvo et al.[1995], and Erol and van Wijnbergen [1997]. Williamson and M iller [1987], in their extended target zone proposal, investigate rules for the conduct of monetary policy to stabilize real exchange rates between cooperating countries. According to the authors, countries should determine a consistent set of real exchange rate targets chosen as to avoid prolonged real exchange rate misalignments and ensure medium-to longer-run current account equilibrium. However, in discussing the merits of real exchange rate rules, these studies have paid little attention to the supply-side effects of real exchange rate changes. In practice, there are direct links between the financial system and the aggregate supply side of the economy that play an important role at various stages of the analysis that follows. The present paper examines these effects in the context of a discrete macroeconomic model in which the authorities pursue an explicit target for the real exchange rate, and thus stands in sharp contrast to these previous studies. The paper also allows for sticky prices since the behavior of real exchange rates may be more consistent with sticky price models. For instance, M ussa [1986] argued that the close correlation between real and nominal exchange rates can best be explained by models in which nominal price levels are sticky.

The model employed in this paper is a modified version of that used by Paschakis and Smithin [1998]. Their formulation is extended to include sticky prices and an aggregate demand which is generated by the quantity equation. Also, the consumer price index rather than the price of domestic output is used in the definition of the real interest rate. This allows the real exchange rate expected in the next period to enter the output-supply equation. In addition, the model involves some interesting characteristics. First, it emphasizes the link between real economic activity and the financial market. This link is revealed by the presence of the real interest rate and real exchange rate in the employment and output equations. In this set-up, the real rate of interest depresses both output and employment via the cost of working capital. Second, it explicitly involves the accumulation of foreign assets (debts) via current account surpluses (deficits). Third, the model allows for imperfect asset substitutability between domestic and foreign assets. This creates interest differentials and thus an additional channnel through which monetary policy could have real effects. 
The paper is organized as follows. Section II introduces the model. Section III obtains the solutions of the model and discusses the implications of the findings. Section IV presents some conclusions.

\section{The Analytical Framework}

\section{A. The Labor and Goods Market}

An important feature of the model is that production takes time. The existence of a production lag is modelled by assuming that labor services at time $t$ yield finished output at time $t+1$. Also, in this set-up, firms pay wages at the beginning of the production process (that is, at time $t$ ), and they are able to finance production by borrowing from the banks for one period at the ongoing nominal interest rate. Firms have no initial liquidity (Calvo and Kumar [1994]).

At the beginning of each period the representative firm chooses labor input, $L$, so as to maximize the sum of expected discounted value of profits. ${ }^{3}$ Thus, taking into account the one-period lag, the firm maximizes

$$
\sum_{i=0}^{\infty}\left[E_{t+i-1}{ }^{t+i-1}\left(P_{t+i} X_{t+i-1}-\left(1+i_{t+i-1}\right) W_{t+i-1} L_{t+i-1}\right)\right],
$$

subject to a Cobb-D ouglas production technology

$$
X_{t}=A_{0} L_{t}{ }^{1}{ }_{t}, A_{0}>0 \quad 0<{ }_{1}<1,
$$

where $P$ is the price of domestic output (in terms of domestic currency), (W) the nominal wage, is a discout factor, and $t$ is a random productivity shock with mean equal to unity and constant variance. Differentiating with respect to $L_{t}$, the first-order condition to the firm's problem is

$$
E_{t}\left[{ }^{t} P_{t+1}{ }_{1} A_{0} L_{t}{ }^{1-1}{ }_{t}-\left(1+i_{t}\right) W_{t}\right]=0,
$$

where the operator $E_{t}$ denotes the mathematical expectation conditional on the information available to the firm at the beginning of period $t$, and $E_{t} t_{t}=1$. In what follows, lower-case letters denote the natural logarithm of

3. In this formulation, an infinite-period maximization problem is equivalent to a sequence of single-period maximizations. 
the corresponding upper-case letter variables as in $\log X_{t}=x_{t}$, and we use the approximation that $\log \left(1+i_{t}\right)=i_{t}$. Thus, equation (3) implies that

$$
\mathbf{4}=-1 /\left(1-{ }_{1}\right)\left[i_{t}+{ }_{t}-E_{t} p_{t+1}-\log \left({ }_{1} A_{0}\right)\right] \text {. }
$$

The real exchange rate is given by $Q_{t}=S_{t} P_{t}^{*} / P_{t}$. Taking logarithms,

$$
q_{t}=s_{t}+p_{t}^{*}-p_{t},
$$

where $q_{t}$ is the log of the real exchange rate, $s_{t}$ is the log of the spot exchange rate defined in local currency units per foreign currency unit, and $p_{t}^{*}$ is the log of the foreign price level (in terms of foreign currency). A rise in $q_{t}$ represents a real exchange depreciation, and hence an improvement in international competitiveness. Being the relative price between the goods the country imports and exports, $q_{t}$ is expected to be an important variable in the determination of the actual amounts exported and imported, and therefore the trade balance surplus (see Rodriguez [1981]). It also implies a terms of trade effect on aggregate output.

The log of the consumer price index, $z_{t}$, is a weighted average of the price of the domestic good, $p_{t}$, and the price of the foreign good expressed in terms of domestic cur rency, $\left(p_{t}^{*}+s_{t}\right)$,

$$
\begin{aligned}
z_{t} & =p_{t}+1(-)\left(p_{t}^{*}+s_{t}\right) \\
& =p_{t}+(1-) q_{t}, 0<\quad<1
\end{aligned}
$$

where and (1- ) are the shares of domestic and imported final goods in domestic consumption. ${ }^{4}$ It is assumed that the domestic economy faces a given foreign price, set for convenience equal to one so that its natural logarithm equals zero (i.e., $\log P_{t}^{*}=p_{t}^{*}=0$ ). Also, the home ex ante real interest rate, $r_{t}$, is equal to the domestic nominal interest rate, $i_{t}$, minus the expectation of the one-period-ahead rate of domestic inflation, $E_{t}\left(z_{t+1}-z_{t}\right)$. That is,

$$
\begin{aligned}
r_{t} & =i_{t}-E_{t}\left(z_{t+1}-z_{t}\right) \\
& =i_{t}-1(-) E_{t}\left(q_{t+1}-q_{t}\right)-E_{t}\left(p_{t+1}-p_{t}\right),
\end{aligned}
$$

4. The analysis could also be cast in terms of traded and non-traded goods. For our purposes not much is lost by using a simpler formulation. 
where $E_{t}\left(q_{t+1}-q_{t}\right)$ is the expected rate of change in the real exchange rate.

Analogous equations describe the rest of the world, which for simplicity consists of a single country. Thus, letting an asterisk denote a foreign variable:

$$
\begin{aligned}
z_{t}^{*} & ={ }^{*} p_{t}^{*}+1\left(-{ }^{*}\right)\left(p_{t}-s_{t}\right) \\
& =p_{t}^{*}-\left(1-{ }^{*}\right) q_{t}, 0<{ }^{*}<1
\end{aligned}
$$

where ${ }^{*}$ and $\left(1-{ }^{*}\right)$ measure the shares of income the foreign country spends on the foreign good and the domestic good. Also, denoting the foreign nominal interest rate by $i_{t}^{*}$, the foreign ex ante real interest rate is:

$$
\begin{aligned}
r_{t}^{*} & =i_{t}^{*}-E_{t}\left(z_{t+1}^{*}-z_{t}^{*}\right) \\
& =i_{t}^{*}+\left(1-{ }^{*}\right) E_{t}\left(q_{t+1}-q_{t}\right),
\end{aligned}
$$

where the real interest rates are defined in terms of a weighted average of domestic and foreign output prices as opposed to the prices of locally-produced output. ${ }^{5}$

Combining equations (4) and (7), the labor demand schedule is derived as

$$
\mathbf{4}=c_{0}-c_{1}\left({ }_{t}-p_{t}\right)-c_{1} r_{t}-c_{1}(1-) E_{t}\left(q_{t+1}-q_{t}\right), \quad c_{0}, \quad c_{t}>0,
$$

where $c_{0}=\log \left(c_{i} A_{0}\right) /\left(1-c_{i j}\right)$, and $c_{1}=1 /\left(1-c_{i j}\right)$. Labor demand depends negatively on real wages, the real interest rate, and the expected percentage change in the real exchange rate. Labor supply is assumed to be a positive function of the purchasing power nominal domestic wage:

$$
\begin{aligned}
\mathbf{H} & =h_{0}+h_{1}\left({ }_{t}-z_{t}\right) \\
& =h_{0}+h_{1}\left({ }_{t}-p_{t}\right)-h_{1}(-) q_{t}, \quad h_{0}, \quad h_{1}>0 .
\end{aligned}
$$

Since a higher real exchange rate raises cost of living and lowers real wage, it reduces labor supply. Both $p_{t}$ and $z_{t}$ play a role in the macro model. For instance, in the labor market the real wage from the worker's perspective is

5. We defined the real exchange rate using the price of domestic output rather the CPI following Fischer (1988) and Romer (1993), and a number of other authors. If the real exchange rate is defined in terms of the CPI, then $q_{t}=s_{t}+z_{t}^{*}-z_{t}=\left(+{ }^{*}-1\right)\left(s_{t}-p_{t}\right)$. The two are closely related. 
the nominal wage deflated by consumer prices, where as the real wage to the firm involves deflating the nominal wage by producer prices.

Setting the demand for labor equal to the supply of labor, yields the following producer 's real wage

$$
{ }_{t}-p_{t}=\frac{\left(c_{0}-h_{0}\right)}{\left(c_{1}+h_{1}\right)}-\frac{c_{1}}{\left(c_{1}+h_{1}\right)} r_{t}-\frac{c_{1}(1-)}{\left(c_{1}+h_{1}\right)} E_{t}\left(q_{t+1}-q_{t}\right)+\frac{h_{1}(1-)}{\left(c_{1}+h_{1}\right)} q_{t} .
$$

In (12) the real wage is a positive function of the real exchange rate, $q_{t}$, a negative function of the real interest rate, $r_{t}$, and a decreasing function of the expected percentage change in the real exchange rate, $E_{t}\left(q_{t+1}-q_{t}\right)$.

Now inserting the equilibrium real wage back into the labor demand schedule, and the resulting level of employment into the log-linear form of the production function gives the following open-economy output-supply function:

$$
x_{t}={ }_{0}-{ }_{1} r_{t}-{ }_{2} E_{t} q_{t+1}+{ }_{t}, \quad 0, \quad{ }_{1}, \quad 2>0,
$$

where $\quad 0=\left[{ }_{0}\left(c_{1}+h_{1}\right)+{ }_{1}\left(c_{0} h_{1}+c_{1} h_{0}\right)\right] /\left(c_{1}+h_{1}\right), \quad{ }_{1}={ }_{1} c_{1} h_{1} /\left(c_{1}+h_{1}\right)$, and $\left.{ }_{2}={ }_{1} c_{1} h_{1}(1-) / \phi_{1}+h_{1}\right)$. Note also that ${ }_{0}=\log A_{0}$ and ${ }_{t}=\log { }_{t}$. In most open economy macroeconomic models, the effects of real interest rates on aggregate supply are ignored, but here real interest rates as well as the real exchange rate are assumed to determine current output. First, the real interest rate appears in the output equation by potentially affecting labor demand. A higher real interest rate makes working capital finance (labor input) more costly, thereby reducing aggregate supply. ${ }^{6}$ Second, the expected value of the next period's real exchange rate, $E_{t} q_{t+1}$, enters as a second relative price, effect on aggregate supply, allowing foreign influences to be transmitted to current output. For given values of import prices, $p_{t+1}^{*}$, output supply is a decreasing function of the real exchange rate expected in the next period, $E_{t}\left(s_{t+1}-p_{t+1}\right)$. Domestic output is also affected by a random

6. This output supply equation incorporates the influence of the real rate on labor demand via working capital considerations, while it abstracts from the influence of the real rate on labor supply via intertemporal substitution. Hercowitz [1986] provides empirical evidence in favor of the supply-reducing effects of high real interest rates. 
productivity disturbance, $t$.

\section{B. Domestic and the Balance of Payments}

M oney demand is given by

$$
y_{t}=m_{t}-z_{t},
$$

where $\left(m_{t}-z_{t}\right)$ is the logarithm of real money balances and $y_{t}$ is real income. The money supply is deflated by the consumer price index, $z_{t}$, rather than the price of domestic good, $\mathrm{p}_{\mathrm{t}}$. Equation (14) can be viewed simply as a shortcut way of modelling aggregate demand. ${ }^{7}$

Since output in period t- 1 is only ready for sale in period $t$, goods-market equilibrium obtains when

$$
y_{t}=x_{t-1},
$$

where $y_{t}$ is current period's demand (see M ackinnon and Smithin [1993]).

The home current account surplus in period $t$ is taken to be equal to the trade surplus plus the interest income received on the domestic country's holdings of net foreign assets: $C A_{t}=T A_{t}+r_{t-1}^{*} B_{t-1}$. The current account surplus also equals the rate of accumulation of net foreign assets from period t1 to t: $C A_{t}=B_{t}-B_{t-1}$, where $B_{t}\left(=F_{t}^{p}+F_{t}^{g}\right)$ represents both private and official net asset holdings. If $B_{t}$ is increasing, the economy runs a current account surplus; while if $\mathrm{Bt}$ is decreasing, the economy runs a current account deficit. 8 This implies that $\left(B_{t}-B_{t-1}\right) / B_{t-1}=T A_{t} / B_{t-1}+r_{t-1}^{*}$. We make the simplified assumption that the trade account surplus expressed as a percentage of the inherited net foreign assets depends only on the logarithm of the real exchange rate and real output: $t s_{t}={ }_{1} q_{t}-{ }_{2} x_{t}$. Therefore,

$$
b_{t}-b_{t-1}={ }_{1} q_{t}-{ }_{2} x_{t}+r_{t-1}^{*}, \quad{ }_{1}, \quad{ }_{2}>0 .
$$

where $b_{t}$ is the logarithm of the real net foreign asset holdings of the gov-

7. Equation (14) could arise from a cash-in-advance constraint or from an assumption that money enters the utility function; alternatively, it can be justified by use of a simple IS-LM model with a vertical LM curve. See Romer [1993].

8. Here, it is assumed that both the private sector and the government hold foreign bonds; for simplicity, neither holds non-interest-bearing foreign currency. 
ernment and the private sector, and $\left(b_{t}-b_{t-1}\right)$ represents the instantaneous change in the stock of net foreign assets resulting from a given current account position.

The condition that ${ }_{1}>0$ implies that the $M$ arshall-Lerner conditions hold. A real exchange rate appreciation ( $a$ decrease in $q_{t}$ ) tends to increase the net trade deficit, thereby reducing demand for domestic output. This effect increases the foreign holdings of domestic securities. On the other hand, a fall in current period's domestic output (that is, a fall in current income) induces a fall in the net trade deficit which reduces real net foreign debt.

\section{The Foreign Exchange Market}

We allow for imperfect asset substitutability by introducing an endogenous risk premium in the foreign exchange market. The relationship between domestic and foreign interest rates is then given by: $i_{t}-i_{t}^{*}=E_{t}\left(s_{t+1}\right.$ $\left.-s_{t}\right)+{ }_{t}$, where ${ }_{t}$, is a risk premium and $E_{t}\left(s_{t+1}-s_{t}\right)$ is the expected rate of depreciation of the domestic currency. Converting the nominal interest rates into real rates plus the inflation rates using (7) and (9), the equilibrium condition for the foreign exchange market becomes

$$
r_{t}-r_{t}^{*}=\left(+{ }^{*}-1\right) E_{t}\left(q_{t+1}-q_{t}\right)+{ }_{t} .
$$

The real interest differential is equal to a constant term times the expected percentage change in the real exchange rate plus a time-varying exchange risk premium. The term $\left(+{ }^{*}-1\right)$ stems from the fact that the consumer price indexes rather than the prices of domestic and foreign outputs are used in the definitions of the inflation rates. Also, abstaining, for simplicity, from foreign price changes, the expected rate of change in the real exchange rate, $E_{t}\left(q_{t+1}-q_{t}\right)$, is decomposed into the difference between the expected percentage change in the nominal exchange rate, and the expected percentage change in the domestic price level $E_{t}\left(p_{t+1}-p_{t}\right)$, i.e., $E_{t}\left(q_{t+1}-q_{t}\right)=E_{t}\left(s_{t+1}-s_{t}\right)-E_{t}\left(p_{t+1}-p_{t}\right)$. Following Branson (1985), and Khan and Zahler (1985), the risk premium, ${ }_{t}$, is expressed as a linear function of the ratio of the real net foreign assets (debts) to output, $\left(b_{t}-x_{t}\right)$, and a constant, $0 .{ }^{9}$ Thus,

$$
{ }_{t}=0-{ }_{1}\left(b_{t}-x_{t}\right), \quad 1>0,
$$


where the (stock of) net foreign assets is assumed to be denominated in the foreign currency. An increase in real net foreign assets (debts) is assumed to decrease (increase) the risk premium on the domestic currency, because foreign investors demand a lower (higher) rate of return than the real interest differential in return for the risk of holding domestic-currency denominated assets. In this case, the divergence of real interest rates may be exploited by monetary authorities for policy purposes.

\section{The Exchange Rate Rule}

Within this framework, the monetary authorities implement an exchange rate rule that maintains constant the real exchange rate. This is achieved by adjusting the nominal exchange rate to offset changes in domestic prices (foreign price, $p_{t}^{*}$, is assumed here to be fixed). Therefore,

$$
q=s_{t}-p_{t}
$$

where $q$ is the target level of the real exchange rate. ${ }^{10}$

The government can use monetary policy to pursue an explicit target for the real exchange rate (see Fischer [1988] and Sachs [1985]). Restrictive monetary policy tends to raise the domestic interest rate causing a nominal exchange rate appreciation, while expansionary monetary policy lowers the domestic nominal interest rate leading to a currency depreciation. Foreign nominal interest rates either are unchanged or increase (decrease) less than the domestic rate because of equation (17) (i.e., the assumption of imperfect assets substitutability). We assume that the real exchange rate target is chosen to equilibriate long-run balance of payments and prevent a "run" on official foreign assets. ${ }^{11}$ Bruno [1995] points out that an important condition for the real exchange rate to be a policy variable is that a nominal

9. This factor appears to be one major explanatory variable of risk premium. Because net foreign assets (indebtedness) change overtime, one should expect to find a risk premium that is equally unstable. See Giddy [1994, p. 169].

10. In this paper, we assume that agents can observe the current price level. H owever, if price indexes are known with a lag, then the real exchange rule will be based on lagged prices. In this case, $Q_{t}=S_{t} P_{t-1}^{*} / P_{t-1}$. Expressed as natural logarithms: $q_{t}=s_{t}-$ $p_{t-1}$, where $p_{t-1}^{*}$ is assumed to be fixed. 
devaluation will not lead to currency substitution and an outburst of inflation. In this case, the sticky-price adjustment assumption is crucial for the real exchange rate to be a policy variable. With sticky prices, a nominal devaluation would translate into a real depreciation. While it is true that real factors may influence the real exchange rate, Obstfeld [1985] and Sachs [1985] link fluctuations in the real exchange rate to changes in monetary policy. Also, Rogers [1999] presents empirical evidence that monetary shocks are generally ver y important for real exchange rate determination.

\section{Solution of the Model}

The set of equations (6), (8), (13), (14), (16), (17), and (18) together with the goods market equilibrium condition (15) and the real exchange rate rule (19) constitutes a model with endogenous variables $z_{t}, z_{t}^{*}, x_{t}, r_{t}, y_{t}, m_{t}$, and $b_{t}$. Here the price of domestic output, $p_{t}$ is predetermined; while the foreign real interest rate, $r_{t}^{*}$, and the foreign output price, $p_{t}^{*}$, are assumed to be constant. All variables except interest rates are expressed in logarithms.

The economy operates under a managed float. Because the monetary authorities are committed to buy and sell domestic and foreign securities in order to support the exchange rule (19), the money supply itself is determined endogenously. Also, the rate of growth of domestic credit is not a constant because of the assumption that credit is essential to enable firms to finance their working capital (or labor costs at period t).

The above model is easily solved by the method of undetermined coefficients. Since the technique is fairly well known by now, we will only lightly touch upon all the details of the procedure here. Substituting for $\mathrm{E}_{\mathrm{t}} \mathrm{q}_{\mathrm{t}+1}$ and $\mathrm{q}_{\mathrm{t}}$ in (13), (16), and (17) using $q$, these three equations are sufficient to determine the values of the real variables $x_{t}, b_{t}$ and $r_{t}$ independently of the remaining equations. The proposed reduced-form solutions for $x_{t}, b_{t}$, and $r_{t}$ are linear functions of the "predetermined" variables $b_{t-1}$ and $r^{*}$, the real exchange rate target $q$, and the exogenous random shock ${ }_{t}$. Thus,

11. The government can also use fiscal policy to implement a real exchange rate target. A fiscal expansion raises the domestic interest rate and thus induces a nominal and real appreciation. A fiscal contraction, on the other hand, has the opposite result. 
448 The Advantage of Targeting the Real Exchange Rate.

$$
\begin{aligned}
& b_{t}={ }_{10}+{ }_{11} b_{t-1}+{ }_{12} q+{ }_{13} r_{t}^{*}+{ }_{14 t}, \\
& x_{t}={ }_{20}+{ }_{21} b_{t-1}+{ }_{22} q+{ }_{23} r_{t}^{*}+{ }_{24 t}, \\
& r_{t}={ }_{30}+{ }_{31} b_{t-1}+{ }_{32} q+{ }_{33} r_{t}^{*}+34 t
\end{aligned}
$$

Consequently, substituting (21) and (22) into (13), (20) and (21) into (16), and (20), (21), and (22) into (17), and noting that $E_{t} q_{t}=E_{t} q_{t+1}=q$, yields

$$
\begin{gathered}
0-{ }_{11}\left({ }_{30}+{ }_{31} b_{t-1}+{ }_{32} q+{ }_{33} r_{t}^{*}+{ }_{34}\right)-{ }_{2} q+{ }_{t} \\
={ }_{20}+{ }_{21} b_{t-1}+{ }_{22} q+{ }_{23} r_{t}^{*}+{ }_{24}, \\
b_{t-1}+{ }_{1} q-{ }_{2}\left({ }_{20}+{ }_{21} b_{t-1}+{ }_{22} q+{ }_{23} r_{t}^{*}+{ }_{24}{ }_{t}\right)+r_{t-1}^{*} \\
={ }_{10}+{ }_{11} b_{t-1}+{ }_{12} q+{ }_{13} r_{t}^{*}+{ }_{14}, \\
r_{t}^{*}+{ }_{0}-{ }_{1}\left[{ }_{10}+{ }_{11} b_{t-1}+{ }_{12} q+{ }_{13} r_{t}^{*}+{ }_{14}-\left({ }_{20}+{ }_{21} b_{t-1}\right.\right. \\
\left.\left.+{ }_{22} q+{ }_{23} r_{t}^{*}+{ }_{24} t\right)\right]={ }_{30}+{ }_{31} b_{t-1}+{ }_{32} q+{ }_{33} r_{t}^{*}+{ }_{34 t} .
\end{gathered}
$$

The coefficient ${ }_{11}$ on the lagged variable $b_{t-1}$ in (20) determines the dynamic behavior of the system (the effects on current endogenous variables of their own lagged values). If ${ }_{11}$ is less than 1.0 in absolute value, then the behavior of net foreign asset holdings $b_{t}$ is stable. Equating the coefficients on $b_{t-1}$ in (23), (24), and (25) implies the following identities:

$$
\begin{aligned}
& 21=-1_{31}, \\
& { }_{11}=1-{ }_{2} 21, \\
& 31=-{ }_{1}\left(11-{ }_{21}\right) .
\end{aligned}
$$

These three relations lead to

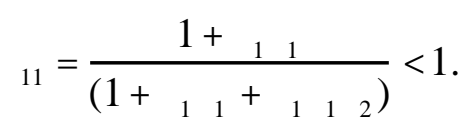

Since the coefficient 11 has absolute value less than one $\left(\begin{array}{lllll}1+ & 1 & 1\end{array}+\begin{array}{lll}1 & 1 & 2\end{array}\right)$ $>\left(\begin{array}{lll}1+ & 1 & 1\end{array}\right)$, the behavior of $b_{t}$ is non-explosive. That is, $b_{t}$ will converge (in an expected-value sense) to its long-run equilibrium position. Therefore, the system of equations (13), (16), and (17) is stable.

\section{A. Steady-State E ffects}


We now consider the long-run or steady-state properties of the model. The steady-state of the economy is determined by suppressing the time subscript $t$ and dropping the disturbance term $\eta_{\text {t }}$. Also, in the steady state, expectations are realized, and $b_{t}=b_{t-1}=b$ for all $t$.

Now, given the real exchange rate target $q$, the steady-state output level is obtained by the balance of payments equation (16). Then given the steadystate output value, the steady-state real interest rate and real net foreign asset holdings are given by the output equation (13) and the foreign exchange market equilibrium expression (17). Thus:

$$
\begin{aligned}
& x=\frac{1}{2} q+\frac{1}{2} r^{*}, \\
& r=\frac{0}{1}-\frac{\left({ }_{1}+{ }_{22}\right)}{12} q-\frac{1}{12} r^{*}, \\
& b=\frac{\left(11_{02}-0_{2}\right)}{12}+\left[\frac{\left(1_{1}+22\right)+11_{1}}{12}\right] q \\
& +\frac{\left(1+1_{2}+11\right.}{12} r^{*} .
\end{aligned}
$$

Equations (30), (31), and (32) show that the steady-state (long-run) values of $x_{t}, r_{t}$, and $b_{t}$ are dependent upon the target value of the real exchange rate and the foreign real interest rate.

The steady-state effects of higher pegged values of the real exchange rate on output, the real interest rate, and net foreign assets are obtained by taking the first derivative of $x_{t}, r_{t}$, and $b_{t}$ with respect to $q$. Therefore,

$$
\begin{aligned}
& \frac{x}{q}=\frac{1}{2}>0, \\
& \frac{r}{q}=-\frac{(1+22)}{12}<0, \\
& \frac{b}{q}=\frac{11_{1}+\left({ }_{1}+22\right)}{12}>0 .
\end{aligned}
$$

These expressions show that a more depreciated (a higher) steady state real exchange rate increases the level of output and the net holdings of foreign assets, and reduces the real interest rate. The implication of the result in (33) is that, contrary to the prediction of the theory, targeting the real 
exchange rate at a higher level does not decrease output (i.e., $x / q<0$ ) but, in fact, leads to the opposite prediction.

\section{B. The Debtor Country Case}

The above results were proved for the case where the domestic economy has a net creditor status. If instead the economy is initially a net debtor, the accumulation over time of net foreign indebtedness equals the trade account deficit plus net interest payments on foreign debts. In this case, the trade account deficit expressed as a percentage of the inherited net foreign indebtedness is a negative function of the logarithm of the real exchange rate and a positive function of real output: $t d_{t}=-{ }_{1} q_{t}+{ }_{2} x_{t}$. Thus, equation (16) becomes:

$$
b_{t}-b_{t-1}=-{ }_{1} q_{t}+{ }_{2} x_{t}+r_{t},
$$

where $b_{t}$ is now defined as the logarithm of the consolidated net foreign debt position of the government and the private sector, and $r_{\mathrm{t}-1}$ is the domestic real interest rate at period $t-1$. Here we assume that the risk premium increases with the ratio of foreign indebtedness to output, that is,

$$
{ }_{t}={ }_{0}+{ }_{1}\left(b_{t}-x_{t}\right), \quad{ }_{1}>0 .
$$

Substituting (13) into (36) and (37), and then (37) into (17), the system reduces to two equations. In this case, the proposed reduced-form solutions for the endogenous variables $b_{t}$ and $r_{t}$ are given by

$$
\begin{aligned}
& b_{t}={ }_{10}+{ }_{11} b_{t-1}+{ }_{12} r_{t-1}+{ }_{13} q+{ }_{14} r_{t}^{*}+{ }_{15}, \\
& r_{t}={ }_{20}+{ }_{21} b_{t-1}+{ }_{22} r_{t-1}+{ }_{23} q+{ }_{24} r_{t}^{*}+{ }_{25}{ }_{t} .
\end{aligned}
$$

Since there are two lagged variables, the local stability of the system depends on the matrix of coefficients:

$$
A=\left[\begin{array}{ll}
11 & 12 \\
21 & 22
\end{array}\right]
$$

In this case, the coefficients of interest are given by 


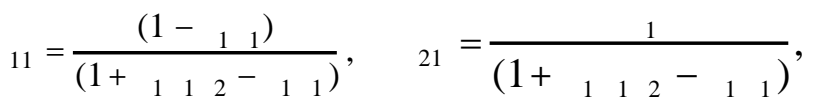

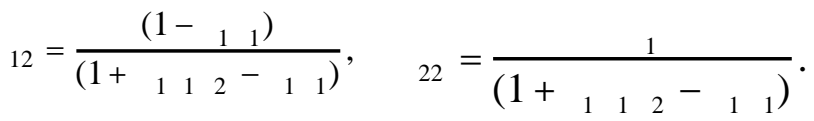

The determinant is equal to zero, implying that the system may be unstable; any small shock would drive both the net foreign debt and the real interest rate away from equilibrium. Thus, if the economy is a net debtor, a real exchange devaluation (depreciation) may cause a higher real interest rate and a deterioration of the current account, implying greater net foreign indebtedness. ${ }^{12}$

\section{Short-R un Solution}

The impact or short-run solutions for the real variables $x_{t}, b_{t}$ and $r_{t}$ can be obtained by solving for the remainder ij coefficients in (23), (24), and (25). U pon substituting these coefficients into (20), (21), and (22), we obtain the complete solutions for the net foreign asset holdings, real output and the real interest rate in terms of structural parameters. Hence,

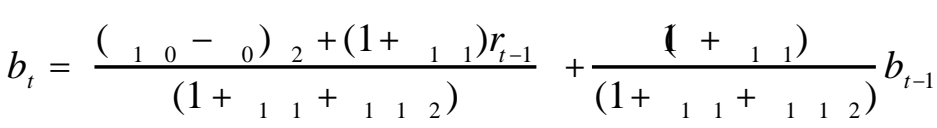

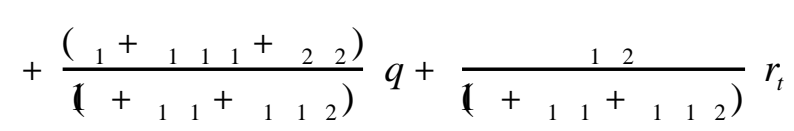

$$
\begin{aligned}
& -\frac{2}{\left(1+\begin{array}{llll}
1 & 1 & & \\
& 1 & 12
\end{array}\right)} t \text {, }
\end{aligned}
$$

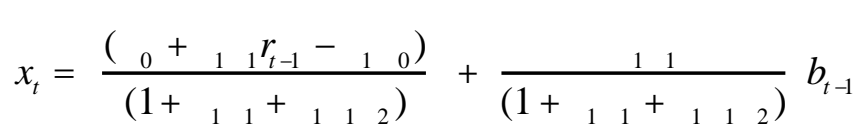

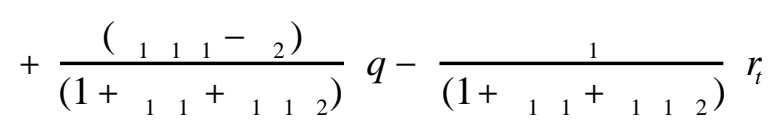

12. In the present context, the potential instability associated with a "net debtor position" is related to the problem of dynamic instability encountered with a net debtor position in foreign assets by Henderson and Rogoff (1982). 


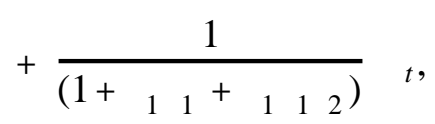

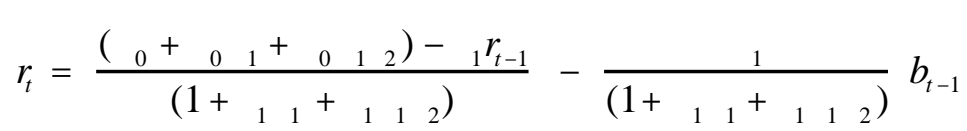

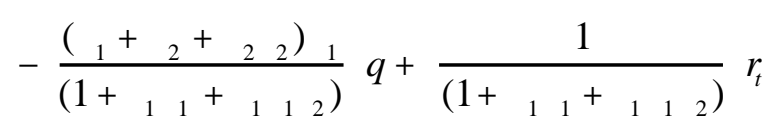

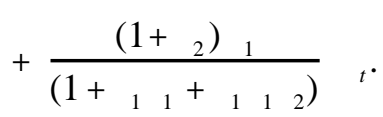

Equations (41), (42), and (43) indicate that a more depreciated level of the real exchange rate increases real net external assets, reduces the real interest rate, and has an ambiguous effect on real output. Also, lagged net foreign asset holdings have a positive effect on $b_{t}$ and $x_{t}$, and a negative effect on $r_{\mathrm{t}}$. Further, an increase in the foreign real interest rate will decrease the level of output, and will increase net foreign assets and the domestic real interest rate.

It is also important to see the behavior of the trade surplus resulting in this case. Substituting from (42) into the trade surplus equation, $t s_{t}={ }_{1} q_{t}-{ }_{2} x_{t}$, yields

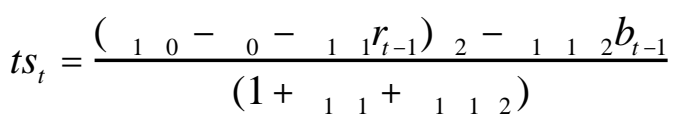

$$
\begin{aligned}
& +\frac{\left({ }_{2}+111+22\right) q+12 r_{t}^{*}-2 t}{\left(1+{ }_{11}+112\right)},
\end{aligned}
$$

while the effect of a higher pegged value of the real exchange rate on the domestic trade surplus is given by

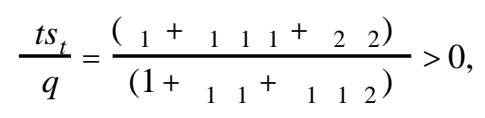

which is the same as the effect of $q$ on $b_{t}$ in (41). The trade surplus increases unambiguously with a higher pegged value of the real exchange rate, corresponding to which the capital account deteriorates. These results indicate that countries that implement nominal exchange rate targets and experi- 
ence balance of payment problems can improve the external competitiveness and the trade account by pursuing periodical devaluations. For instance, all of the European countries that devalued in 1992 had experienced a substantial decrease in real interest rates, and improvement in the current account and real economic activity afterward (see Dornbusch et al. [1995]). This is particularly true of Italy and the United Kingdom. Following the devaluation of 1992, both these countries experienced low real interest rates and a remarkable improvement in the current account (by mid-1993 the deficit had disappeared in Italy) and real growth (see Giavazzi [1996]).

\section{Price Stickiness and E ndogenous Money Supply}

Following Obstfeld [1995], the price of the domestically produced good is a geometric average of the previous period's price and newly posted prices, denoted by $k$, with $(1+)$ measuring the fixed probability that a price is revised in each period: $:^{13}$

$$
p_{t}=p_{t-1}+(1-) k_{t}
$$

The parameter 8 represents both the (exogenous, constant) probability that a price is not renewed, and the proportion of old prices that continue in effect. Thus, 8 measures the degree of price sluggishness.

Newly posted prices are a distributed lead on expected future CPIs and aggregate demand, with expectations for different future dates discounted by the probability that a price newly posted will "survive" until then:

$$
k_{t}=(1-) \sum_{i=0}^{\infty}{ }^{i} E_{t-1}\left[p_{t+i}+(1-)\left(p_{t+i}^{*}+s_{t+i}\right)+y_{t+i}\right] \text {. }
$$

In equation (47), measures the response of new prices to expectations about future demand conditions.

We can rewrite equations (46) and (47) using lag and lead operators. Let $L$ denote the lag operator, such that $L x_{t}=x_{t-1}$ for any variable $x$, and let $L^{-1}$ be its inverse, the lead operator, such that $\mathrm{L}^{-1} \mathrm{X}_{\mathrm{t}}=\mathrm{x}_{\mathrm{t}-1}$. Thus, we can rewrite the average price of domestic output, (46), as

13. The price adjustment is based on Calvo [1983]. 


$$
(1-L) p_{t}=(1-) k_{t} \text {. }
$$

Also, newly posted prices, from equation (47), can be expressed as

$$
k_{t}=\frac{(1-) E_{t-1}\left[p_{t}+(1-)\left(p_{t}^{*}+s_{t}\right)+y_{t}\right]}{1-L^{-1}} .
$$

Together these last two equations show that $p$ follows the second-order difference equation

$$
\left(-L^{-}\right)(-L) p_{t}=(-) E_{t-}\left[p_{t}+(-)\left(p_{t}^{*}+s_{t}\right)+y_{t}\right]
$$

Using equations (14), (19) and (6), relation (50) can be solved for $\mathrm{p}_{\mathrm{t}}{ }^{14}$ The solution for $\mathrm{p}_{\mathrm{t}}$ can then be first-differenced to yield $\Delta \mathrm{p}_{\mathrm{t}}$. Consequently, equation (6) allows us to obtain $\mathrm{z}_{\mathrm{t}}$ and the CPI inflation, $\Delta \mathrm{z}_{\mathrm{t}}$.

Finally, substituting (6) and (15) into (14), the endogenous money supply is given by

$$
m_{t}=p_{t}+(1-) q+x_{t-1} .
$$

The money supply depends on aggregate demand, the real exchange rate target, and the price of domestic good..$^{15}$

\section{Conclusion}

This paper has employed a simple open-economy macroeconomic framework to explore the implications of real exchange rate targeting for the behavior of real output, the domestic real interest rate, trade account, net foreign asset holdings, and the inflation rate. Recent experience with fixed

14. Obstfeld [1995] obtains the solution of a similar equation. In addition to the money demand equation (14), he also employs a world aggregate demand for domestic output of the form: $y_{t}=\left(s_{t}+p_{t}^{*}-p_{t}\right)+u_{t}$, where $\mathrm{u}_{\mathrm{t}}$ is a random (unexpected) disturbance term.

15. Here we don't explicitly consider changes in the money supply that would arise from central bank purchases and sales of international reserves (the connection between the monetary sector and the overall balance of payments). This assumption simplifies the present analysis considerably without affecting our qualitative conclusions. 
nominal exchange rates has shown that nominal exchange rate targets have generated substantial real exchange rate over-valuations, and thus have adversely affected the behavior of some of these variables in high inflation countries. The findings of this paper indicate that a more depreciated level of the real exchange rate decreases the domestic real interest rate and net foreign debt, and leads to a higher level of output and net exports. The results are consistent with the after-effects of EM S currency re-alignment, which had consisted of lower real interest rates and a significant improvement of international competitiveness, net exports, and real economic activity in the devaluing members of the system. They also imply that a "real targets approach" to exchange rate policy rather than a "nominal anchor approach" may be more appropriate for the European U nion inflation-prone countries and the high inflation developing countries with nominal exchange rate targets.

The results are of some relevance to Canada. In the 1990s, the Canadian economy had experienced stable prices and a gradual depreciation of the dollar against its U.S. counterpart. The consequent real exchange rate depreciation has led to a significant improvement in the Canadian trade surplus and net foreign indebtedness. However, the impact of a real exchange rate target may differ qualitatively depending on whether the economy is a net for eign creditor or debtor. If the economy is a net debtor, a real exchange devaluation leads to dynamic instability, causing the net foreign debt and real interest rate to move away from equilibrium. In the net creditor case, the system is stable. Thus, a real exchange devaluation results in an improvement in the net foreign asset position and a reduction in the real interest rate.

One criticism of real exchange rate targeting is that it is inherently inflationar y. This aspect is discussed in Adams and Gros [1985], and Calvo et al. [1995]. In this paper, however, given price stickiness, real exchange rate targeting may not lead to higher rates of domestic inflation. Also, the monetary authorities do not know what a sustainable level of the real exchange rate is. Unless by chance they are able to hit the correct level at the time of the fixing, further adjustment will be necessary to prevent real exchange over-valuations. The EM S experience has shown that a number of EM S members had failed to choose a "appropriate" level for the real exchange rate at the 
time of joining the ERM, and thus had experienced pressures for realignment afterwards. Further, it has also been understood that non-monetary considerations can influence the behavior of the real exchange rate. In particular, the "Balassa-Samuelson effect" means that the degree of differential productivity growth in tradable goods relative to non-tradable goods explains the rate of increase in a currency's relative external purchasing power. ${ }^{16}$ Empirical findings, however, detect only a weak relation between productivity variables and measures of the real exchange rate. According to Obstfeld [1995], these findings are suggestive of a Balassa-Samuelson effect, but not conclusive.

\section{References}

Adams, Charles and Daniel Gros (1986), "The Consequences of Real Exchange Rate Rules for Inflation: Some Illustrative Examples," International M onetary F und Staff Papers 33; 439-476.

Branson, William H. (1985), "Causes of Appreciation and Volatility of the Dollar," Reprint 785, NBER (National Bureau of Economic Research), in The US \$--Recent Developments Outlook and Policy Options, Federal Reserve Bank of Kansas City.

Bruno, M icheal (1995), "Comment" on Rudiger Dornbusch, Ilan Goldfajn, and Rodrigo 0. Valdés: "Currency Crises and Collapses," Brookings Papers on E conomic Activity 2; 278-285.

Calvo, Guillermo A. (1983), "Staggered Prices in a Utility-M aximizing Framework," Journal of M onetary E conomics 12; 383-398.

Calvo, Guillermo A. and M anmohan S. Kumar (1994), "Money Demand, Bank Credit, and Economic Performance in Former Socialist Economies," International M onetary Fund Staff Papers 41; 314-349.

Calvo, Guillermo A., Carmen M. Reinhart and Carlos A. Végh (1995), "Targeting the Real Exchange Rate: Theory and Evidence," Journal of Development E conomics 47; 97-133.

Dornbusch, Rudiger (1982), "PPP Exchange-Rate Rules and M acroeconomic Stability," Journal of Political Economy 90; 158-165.

16. We would like to thank an anonymous referee for making this point. 
Dornbusch, Rudiger (1989), "Europe 1992: M acroeconomic Implications," B rookings Papers on Economic Activity 2; 341-362.

Dornbusch, Rudiger, Ilan Goldfajn and Rodrigo O. Valdés (1995) ,"Cur rency Crises and Collapses," B rookings Papers on E conomic Acti vity 2; 219293.

Edwards, Sebastian (1996), "Exchange-Rate Anchors, Credibility, and Inertia: A Tale of Two Crises, Chile and M exico," American Economic Review Papers and Proceedings 86; 176-180.

Erol, Turan and Sweder van Wijnbergen (1997), "Real Exchange Rate Targeting and Inflation in Turkey: An Empirical Analysis with Policy Credibility," World Development 25; 1717-1730.

Fischer, Stanley (1988), "Real Balances, the Exchange Rate, and Indexation:

Real Variables in Disinflation," Quarterly Journal of Economics 103; 27-49.

Giavazzi, Francesco (1996), "Discussion" in J effrey Sachs, Aaron Tomell and Andrés Valasco: "The Collapse of the M exican Peso: What Have we Learned?" E conomic Policy 22; 56-58.

Giddy, Ian H. (1994), Global Financial Markets, Lexington, M A: D. C. Health and Company; 167-169.

Henderson, D. and K. Rogoff (1982), "Negative Foreign Asset Positions and Stability in a World Portfolio Balance M odel," Journal of International Economics 13; 85-104.

Hercowitz, Zvi (1986), "The Real Interest Rate and Aggregate Supply," Journal of M onetary E conomics 18; 121-45.

K han, M ohsin S. and Roberto Zahler (1985), "Trade and Financial Liberalization Given External Shocks and Inconsistent Domestic Policies," International M onetary F und Staff Papers, 32; 22-55.

Klein, M ichael W. (1990), "Playing with the Band: Dynamic Effects of Target Zones in an Open Economy," International Economic Review 31; 757-772.

Lizondo, J. Saúl (1991), "Real Exchange Rate Targets, Nominal Exchange Rate Policies, and Inflation," Revista de Análisis E conómico 6; 5-22.

Lizondo, J. Saúl (1993), "Real Exchange Rate Targeting Under Imperfect Asset Substitutability," International M onetary Fund Staff Papers 40; 829-851. 
M acK innon, Keith and John Smithin (1993), "An Interest Rate Peg, Inflation and Output," Journal of M acroeconomics 15; 769-785.

M ontiel, Peter J . and J onathan D. Ostry (1991), "M acroeconomic Implications of Real Exchange Rate Targeting in Developing Countries," International M onetary F und Staff Papers 38; 872-900.

M ontiel, Peter J . and J onathan D. Ostry (1992), "Real Exchange Rate Targeting Under Capital Controls: Can Money Provide a Nominal Anchor?,"International M onetary F und Staff Papers 39; 58-78.

M ussa, M ichael (1986), "Nominal Exchange Rate Regimes and the Behavior of Real Exchange Rates: Evidence and Implications," in Karl Brunner and Allan H. M eltzer, (eds.), Real Business Cycles, Real Exchange Rates and Actual Policies, Carnegie-Rochester Conference Series on Public Policy, Amsterdam: Nor th-H olland 25, 117-214.

Obstfeld, M aurice (1985), "Floating Exchange Rates: Experience and Prospects," B rookings Papers on E conomic Activity 2; 369-450.

Obstfeld, M aurice (1995), "Inter national Currency Experience: New Lessons and Lessons Relearned, "B Brookings Papers on E conomic Activ ity $1 ; 119-220$.

Paschakis, John and John Smithin (1998), "Exchange Risk and the SupplySide Effects of Real Interest Rate Changes," Journal of Macroeconom ics 20; 703--720.

Rodriguez, Carlos Alfredo (1981), "M anaged Float: An Evaluation of Alternative Rules in the Presence of Speculative Capital Flows," American Economic Review 71; pp. 256-260.

Rogers, John H. (1999), "M onetary Shocks and Real Exchange Rates," Journal of International E conomics 49; 269-288.

Romer, David (1993), "Openness and Inflation: Theory and Evidence," Quarterly Journal of Economics 108; 869-903.

Sachs, Jeffrey (1985), "The Dollar and the Policy M ix: 1985," Brookings Papers on E conomic activity $1 ; 117-185$.

Székely, István (1996), "Discussion" in J effrey Sachs, Aaron Tornell and Andrés Valasco: "The Collapse of the Mexican Peso: What Have we Learned?"'E conomic Policy 22; 58-60.

Williamson, J ohn (1981), Exchange Rate Rules: The Theory, Performance, and Prospects of the Crawling Peg, N ew York: St. M artin's Press. 
Williamson, John and M. M iller (1987), Targets and Indicators: A Blueprint for the International Coordination of Economic Policy, Washington: Institute for International Economics. 